\title{
Correction to: using accounting earnings and aggregate economic indicators to estimate firm-level systematic risk
}

\author{
Ray Ball ${ }^{1} \cdot$ Gil Sadka $^{2} \cdot$ Ayung Tseng $^{3}$ \\ Published online: 28 October 2021 \\ (C) Springer Science+Business Media, LLC, part of Springer Nature 2021
}

\section{Correction to: Review of Accounting Studies https://doi.org/10.1007/s11142-021-09594-9}

The original version of this article unfortunately contained some mistakes in Reference entries and some text citations. Names were set as part of the paper title and Markowitz 1952 was missed. Thus these were corrected as follows:

De Bondt, WFM, and R Thaler. 1985. Does the stock market overreact? J Financ 40: 793-805.

De Bondt, WFM, and R Thaler. 1987. Further evidence on investor overreaction and stock market seasonality. J Financ 42: 557-581.

Gomes, J, L Kogan, and L Zhang. 2003. Equilibrium cross section of returns. J Polit Econ 111: 693-732.

Hubbard, RG, AK Kashyap, and TM Whited. 1993. International finance and firm investment. NBER Working Paper No. 1392.

The online version of the original article can be found at https://doi.org/10.1007/s11142-021-09594-9

Ray Ball

ray.ball@chicagobooth.edu

Gil Sadka

gil.sadka@utdallas.edu

Ayung Tseng

atseng@indiana.edu

1 Booth School of Business, University of Chicago, 5807 SouthWoodlawn Avenue, Chicago, IL 60637, USA

2 University of Texas at Dallas, 800 West Campbell Rd, Richardson, TX 75080, USA

3 Indiana University, 1309 E 10th Street, Bloomington, IN 47401, USA 
Konchitchki, Y, Y Luo, MLZ Ma, and F Wu. 2016. Accounting-based downside risk, cost of capital, and the macroeconomy. Rev Account Stud 21: 1-36.

Lucas, ER. 1990. Why doesn't capital flow from rich to poor countries?. Amer Econ Rev. 80: 92-96.

Manuelli, ER, and A Seshadri. 2014. Human capital and the wealth of nations. Amer Econ Rev. 104: 2736-2762.

Markowitz, Harry, 1952, Portfolio selection, J Finance 7, 77-91.

Mayers, D. 1972. Non-marketable assets and capital market equilibrium under uncertainty. In Studies in the theory of captital markets, ed. C. Jensen, 223-48. Santa Barbara. CA: Praeger.

Moskowitz, TJ, and A Vissing-Jørgensen. 2002. The returns to entrepreneurial investments: A private equity premium puzzle? Amer Econ Rev. 92: 745-778. Petkova, R, and L Zhang. 2005. Is value riskier than growth? J Financ Econ 78: 187-202.

The original paper has been corrected.

Publisher's note Springer Nature remains neutral with regard to jurisdictional claims in published maps and institutional affiliations. 